Jurnal Psikologi Teori dan Terapan

2017, Vol.7, No. 2, 82-87, ISSN: 2087-1708

\title{
Kecerdasan Emosi dan Perilaku Agresi di Social Media Pada Remaja
}

\author{
Waya Ratna Dewi, dan Siti Ina Savira \\ Program Studi Psikologi Universitas Negeri Surabaya
}

\begin{abstract}
This study was aimed to examine the relationship betwen emotional intelligence and aggressive behavior on social media among students of state senior high school (SMA Negeri) 1 " $X$ " in Gresik regency. There were 232 students involved in this study. This study hypothesizes that emotional intelligence is correlated to aggressive behavior on social media among the subjects. Data collected using emotional intelligence and aggressive behavior scales and analyzed using Pearson's product moment. The result shows that the correlation coefficient value is $0,859(r=0,859)$ with the significance level 0.000. The significance level is less than 0,005 $(p<0.005)$ which means that the hypothesis of this study is accepted. It can be concluded from the result that there is a significant correlation between emotional intelligence and aggressive behavior on social media among the subjects. The positive value of the coefficient shows that the higher the level of emotional intelligence of the students, the less aggressive their behaviors on social media will be, and vice versa.
\end{abstract}

Key words: Emotional intelligence, aggressive behavior, social media

\begin{abstract}
Abstrak: Penelitian ini bertujuan untuk mengetahui apakah ada hubungan antara kecerdasan emosi dengan perilaku agresivitas di social media pada remaja SMA Negeri 1 "X" Gresik. Hipotesis kerja (Ha) yang diajukan adalah sebagai berikut. Ada Hubungan antara kecerdasan emosi dengan perilaku agresi di social media pada remaja siswa SMAN 1 "X" Gresik. Subjek dalam penelitian ini adalah 232 siswa. Data dikumpulkan menggunakan kuesioner dalam bentuk skala kecerdasan emosi dan perilaku agresi di media sosial. Teknik analisis data menggunakan korelasi product moment. Hasil analisis data menunjukan nilai koefisien korelasi sebesar $0,859(\mathrm{r}=0,859)$ dengan taraf signifikasi $0,000(\mathrm{p}<0,005)$. Hasil tersebut menunjukkan bahwa ada hubungan yang signifikan antara kecerdasan emosi dengan perilaku agresi di social media pada subjek penelitian, dan nilai positif menunjukan hubungan searah antara dua variabel yaitu kecerdasan emosi dengan perilaku agresivitas di social media. Semakin tinggi tingkat kecerdasan emosi yang dimiliki siswa maka akan semakin rendah perilaku agresi di social media, begitu pula sebaliknya.
\end{abstract}

Kata Kunci: Kecerdasan emosi, perilaku agresi, social media

Masa remaja merupakan masa yang kritis karena pada masa remaja terjadi proses transisis dari masa anak-anak ke masa dewasa di segala aspek atau fungsi perkembangan untuk memasuki masa dewasa (Santrock, 2002). Hall (dalam Santrock, 2002) menjelaskan bahwa perio- de remaja adalah usia 12-23 tahun dan penuh dengan topan (storm) dan tekanan (stress). Masa storm dan stress merupakan masa goncangan yang ditandai dengan konflik dan perubahan suasana hati remaja. Masa remaja awal merupakan suatu masa dimana fluktuasi emosi (naik-turun) sering

Korespondensi tentang artikel ini dapat dialamatkan kepada Waya Ratna.Dewi melalui email: wdw334@gmail.com; atau ke Siti Ina Savira via email: inasavira@unesa.ac.id 
Terjadi (Rosenblum \& Lewis, dalam Santrock, 2007). Remaja diusia awal cenderung tidak memiliki stabilitas emosi shingga mudah untuk fluktuatif atau berubah-ubah emosinya. Remaja akan mengalami gejolak emosi yang meledakledak dan sulit diken-dalikan yang menyebabkan remaja mudah terpengaruh oleh lingkungan tempat tinggalnya, keluarga, sekolah dan teman-teman sebaya (Hurlock, 2011).

Fluktuasi emosi yang dialami remaja disebabkan oleh perubahan-perubahan yang dialami oleh remaja. Perubahan tersebut antara lain fungsi sosial remaja dalam mempersiapkan diri menuju kedewasaan, dimana mereka akan mencari identitas diri serta memantapkan posisinya dalam masyarakat. Perubahan fisik yang dialami remaja berkaitan dengan organ dan fungsi seksual yang semakin matang. remaja juga mengalami perkembangan kognitif dimana pemikiran mereka menjadi lebih kritis serta memiliki penalaran yang lebih tajam. (Hurlock, 2011)

Agresi remaja menunjukkan gejala semakin meningkat bagi dari segi kualitas maupun kuantitas (Santoso, 2004). Agresi Remaja bukan saja terjadi didunia nyata dengan perkembangan teknologi yang semakin pesat remaja meluapkan perilaku agresinya melalui media sosial seperti Facebook, Instagram, Twitter, Black Berry Messenger (BBM) dan yang lainnya. Berita mengenai agresi remaja biasanya berupa kekerasan fisik dan penghinaan di Social Media. Agresi juga dapat dipicu dari social media. misalnya merusak fasilitas sekolah, memukul, berkelahi, tawuran dan update status di social media seperti Facebook kemudian bertengkar di sekolah. (kompas.com, 2016).

Agresi yang terjadi pada remaja memiliki beberapa faktor yang menyebabkan remaja berperilaku agresi (Antasari, 2006). Diantaranya adalah faktor sosial, lingkungan, dan emosi. Faktor sosial merupakan segala keadaan yang berasal dari luar individu remaja yang menjadi penyebab terjadinya perilaku agresi. Provokasi merupakan salah satu faktor sosial yang menyebabkan remaja mau tidak mau akhirnya berperilaku agresi. Faktor lingkungan masyarakat tempat remaja melakukan interaksi sosial turut mempengaruhi terbentuknya sikap agresi remaja. Faktor emosi merupakan kondisi emosional atau kerentanan emosional yang dialami remaja. Zillman (dalam Krahe, 2005) menyatakan bahwa orang-orang yang rentan secara emosional akan memperlihatkan perilaku agresi yang lebih tinggi. Pemahaman yang sama dikemukakan Atkinson (2000) bahwa agresi merupakan reaksi emosi. Sebagai contoh yaitu reaksi dari amarah seseorang yang akan diluapkan melalui perilaku aggressive memukul. Agresi juga merupakan sebuah reaksi primitive dalam bentuk kemarahan hebat dan ledakan emosi tanpa kendali (Lutfi, 2009). Nilai-nilai yang berlaku di masyarakat dimana individu tersebut berada dapat digunakannya sebagai dasar untuk membentuk sikapnya.

Perilaku Remaja yang dijelaskan di atas juga merupakan efek media sosial. Efek media sosial ini tidak hanya dapat mempengaruhi seseorang dalam waktu yang pendek, namun juga dalam waktu yang lama (Bungin, 2006). Bungin (2006) menemukan jika remaja memiliki banyak motif utama dalam menggunakan internet, dan yang sangat penting adalah untuk pencarian infor-masi. Mereka juga menemukan jika seseorang secara interpersonal menggunakan internet utamanya untuk mengumpulkan informasi dan mereka yang merasa tidak aman dalam interaksi tatap muka, lebih memilih menggunakan internet sebagai motif sosial. Sifat "membuka diri" atau self-disclosure pada remaja yang suka online lebih baik daripada yang tidak. LaRose dan Eastin (2010), menjelaskan bahwa media sosial (internet) dapat membuat seseorang beranggapan bahwa jika ia menggunakan 
internet maka ia akan mengembangkan banyak hal dalam hidupnya. Hasil sosialisasi menghasilkan status dan identitas sosial. Turner (2010) menyatakan bahwa seseorang akan meningkatkan status sosial mereka dengan cara mencari orang yang memiliki kesamaan pikir dengan mereka melalui internet dan mengekspresikan ide-ide atau pemikiranpemikiran pada mereka.

Berikut ini sedikit fakta menarik yang menunjukkan perkembangan media sosial yang signifikan Data berdasarkan riset Kementerian Komunikasi dan Informatika di tahun 2011. Pengguna Twitter sudah mencapai 175 juta member, meningkat $133 \%$ dari tahun 2010 yang berjumlah 75 juta member. Tercatat ada sekitar 95 juta tweet per hari, meningkat $250 \%$ dari tahun 2010 yang berjumlah 27 juta tweet per hari. Facebook memiliki 640 juta pengguna aktif, 50\% mengakses Facebook setiap hari (Kominfo.go.id, 2016).

Dampak-dampak yang ditimbulkan dari perilaku agresi di media sosial sangat besar terutama pada remaja. Remaja yang selalu sibuk dengan social media akan mengalami penurunan dalam pengelolaan emosinya sendiri. Remaja sangat mudah meluapkan emosinya di social media tanpa memikirkan dampak kedepannya (Daniel, 2009).

Berdasarkan pernyataan para ahli tersebut dapat dilihat bahwa perilaku agresi berkaitan dengan fungsi emosi, yaitu agresi sebagai reaksi emosi yang tidak terkendali atau berlebihan yang dilakukan remaja dengan tujuan menyakiti pihak lain. Remaja yang tidak mampu mengelola emosi dengan baik akan menyebabkan tidak bisa menolak dorongan negatif, emosi frustasi, serta emosi-emosi negatif lain yang dirasakannya. Agresi merupakan hal umum yang terjadi pada remaja. Presentasi agresi remaja di Gresik bisa dikatakan tidak setinggi daerah lain. keadaan demografisnya, populasi remaja sebagai usia produktif termasuk dalam populasi yang besar dengan jumlah total 692.209 orang (Pemerintah Kabupaten Gresik, 2013). Jumlah populasi yang besar tidak membuat remaja di Gresik melakukan tindak agresi setinggi dan sesering daerah-daerah lain seperti yang telah dipaparkan diatas. Faktor kecerdasan emosi dianggap sebagai salah satu faktor munculnya tindak agresi remaja.

Remaja yang memiliki pengelolaan emosi yang baik dapat mengekspresikan emosi yang dirasakan dengan cara yang poditif, tidak dengan agresi. Remaja memiliki motivasi emosi sehingga remaja dapat mengontrol dan mengarahkan dorongan emosi untuk mencapai tujuan yang positif. Pemahaman, pengelolaan, serta adanya ,motivasi emosi yang positif akan membantu remaja untuk bisa memahami emosi orang lain yang akhirnya berdampak pada terbentuknya hubungan interpersonal yang baik (Shahzad, 2013). Pemahaman emosi diri, pengelolaan emosi, motivasi diri, empati dan terbentuknya hubungan interpersonal merupakan lima kemampuan utama dari kecerdasan emosi (Salovey, dalam Goleman, 2007).

Fenomena yang terjadi adalah semakin banyak jenis social media yang digunakan oleh remaja saat ini. Remaja dapat meluapkan apa yang dia rasakan disocial media sehingga tidak memikirkan dampaknya didunia nyata. Hal ini sangat berhubungan dengan kecerdasan emosional yang dimiliki oleh masing-masing remaja. Peneliti ingin meneliti dinamika kecerdasan emosional dengan agresi di social media yang terjadi pada remaja.

Oleh karena itu peneliti tertarik melakukan penelitian terkait dengan hubungan antara kecerdasan emosi dengan perilaku agresi di social media pada remaja siswa SMA Negeri 1 "X" Gresik.

\section{Metode}

Metode yang digunakan adalah metode kuantitatif dengan menggunakan rancangan penelitian korelasi. Penelitian ini 
akan menghubungkan variabel kecerdasan emosi dengan perilaku agresivitas di social media.

Populasi penelitian ini adalah seluruh siswa SMA Negeri 1 "X" Gresik yang terdiri dari 30 kelas dengan populasi sebanyak 756 orang dengan subjek penelitian yang diambil sebagai sampel menggunakan rumus slovin dengan taraf kesalahan 5\% yaitu berjumlah 262 siswa.

Teknik pengumpulan data pada penelitian ini dilakukan dengan memberikan skala yang diisi oleh sampel penelitian. Skala yang dibagikan kepada sampel penelitian terdiri atas dua skala yakni, skala kecerdasan emosi dan skala agresivitas di social media. Dimana kedua skala tersebut menggunakan model skala likert. Teknik analisis data yang digunakan oleh peneliti menggunakan teknik analisis product moment yang dibantu menggunakan program SPSS 23.0 for windows.

\section{Hasil}

Hasil analisis dari korelasi product moment menunjukkan bahwa nilai signifikansi variabel kecerdasan emosi dan variabel perilaku agresi di social media adalah $\mathrm{p}=0.000(\mathrm{p}<0.05)$. Nilai signifikansi tersebut lebih kecil dari 0.05 karena itu kedua variabel tersebut dapat dinyatakan memiliki hubungan yang signifikan. Berdasarkan pada hasil tersebut, hipotesis yang menyatakan bahwa "Ada hubungan antara kecerdasan emosi dengan perilaku agresi di social media pada siswa SMAN 1 "X" Gresik" dapat diterima. Hasil analisis juga menunjukkan bahwa koefisien korelasi antara kecerdasan emosi dengan perilaku agresi di Social Media yaitu sebesar $\mathrm{r}=$ 0,859. Skor tersebut menunjukkan bahwa hubungan antara kecerdasan emosi dan perilaku agresi dalam social media merupakan hubungan yang Sangat Kuat.

\section{Pembahasan}

Hasil penelitian ini menunjukkan bah- wa kecerdasan emosi dengan perilaku agresi di social media pada remaja memiliki hubungan yang kuat dan bersifat searah atau positif. Hal ini berarti semakin besar kecerdasan emosi maka akan semakin tinggi munculnya perilaku agresivitas di social media. Hasil ini sesuai dengan prediksi teoritis bahwa ada hubungan antara kedua variabel tersebut, namun bertolakbelakang dengan asumsi teoritis terkait sifat hubungannya yang positif atau searah. Secara teoritis, meningkatnya kecerdasan emosi akan terkait dengan menurunnya perilaku agresi di social media. Hasil yang tidak sesuai dengan asumsi teoritis ini bisa dijelaskan sebagai berikut.

Pertama, temuan penelitian seperti ini dimungkinkan terjadi karena salah satu aspek dari kecerdasan emosi merupakan kemampuan individu dalam memahami dan mengekspresikan apa yang dirasakan oleh dirinya maupun apa yang dirasakan oleh orang lain (Qomariyah, 2012). Dalam media sosial (internet) kemampuan seperti ini dapat berdampak ganda. Kecerdasan emosi dapat berdampak positif pada individu karena dapat memahami emosi dirinya sendiri dan orang lain. Namun kecerdasan emosi juga dapat berdampak negatif ketika individu dapat berlebihan dalam mengungkapkan apa yang dia rasakan dan apa yang orang lain rasakan (Wahyudiono, 2012).

Kedua, agresi yang terjadi di social media cenderung bersifat verbal berbeda dengan agresi secara umum dalam dunia nyata. Agresi bersifat verbal melalui tulisan atau visual ini dapat semakin mudah dilakukan karena pelaku agresi di social media dapat melibatkan pelaku dan korban yang tidak saling kenal atau salah satu pihak tidak mengenali karena media internet memungkinkan penggunanya menyembunyikan identitas dirinya (men-jadikan diri anonim atau menggunakan akun palsu). Dalam hal ini, seorang remaja yang memiliki kecerdasan emosi yang tinggi dimungkinkan memiliki kontrol diri yang 
kuat dalam menjaga emosinya didunia nyata, namun kontrol diri itu bisa melemah jika berada dalam dunia online (internet). Mereka akan lebih mudah mengekspresikan emosinya di dunia maya termasuk social media (Qomariyah, 2012). Sebagai contoh saat individu berkomentar di status orang lain di social media tanpa mengungkapkan jati dirinya orang tersebut dapat mengekspresikan emosinya di social media dengan tanpa kontrol sehingga dapat mengarah salah satunya pada perilaku agresi. Dalam arti lain remaja lebih berani mengekspresikan emosinya di social media (dunia maya) daripada di dunia nyata (Judhita, 2011). Suatu kejadian yang terjadi di dunia maya atau di social media akan berdampak pada kehidupan nyata/konkrit (Wahyudiono, 2012). Karena itu, sekalipun berbeda ranah, agresi dalam dunia nyata maupun dalam dunia internet seperti social media tetap berdampak sama pada korban.

\section{Simpulan}

Dapat disimpulkan dalam penelitian emosi dengan perilaku agresi di social ini bahwa ada hubungan antara kecerdasan media pada remaja. Kesimpulan selanjutnya adalah karena arah hubungan korelasi bersifat positif, maka dapat disimpulkan bahwa semakin tinggi kecerdasan emosi semakin tinggi pula perilaku agresi di social media.

Kesimpulan pertama sesuai dengan beberapa hasil penelitian sebelumnya yang menunjukkan adanya hubungan antara kecerdasan emosi dengan perilaku agresi. Namun, kesimpulan kedua tidak sepenuhnya sesuai dengan asumsi teoritis yang memprediksi bahwa semakin tinggi kecerdasan emosi seseorang, semakin rendah perilaku agresinya.

Penelitian lebih lanjut perlu dilakukan terkait agresi dalam media internet khususnya media sosial dan kaitannya dengan dimensi psikologis seseorang. Perbedaan karakteristik situasi interaksi sosial dalam dunia nyata dan dunia maya (internet) menyebabkan adanya kemungkinan perbedaan dalam penjelasan perilaku agresi dalam konteks dunia maya dan dunia nyata.

\section{Daftar Pustaka}

Anantasari. (2006). Menyikapi Perilaku Agresif Anak. Yogyakarta: Kanisius.

Atkinson, L.R. (2000). Pengantar Psikologi Jilid 2. (terjemahan: Anna kuswarini). Jakarta: Interaksa.

Bungin (2006). Landasan Psikologi Pendidikan. Bandung: PT. Remaja Rosdakarya.

Charles D.F (2009). Electronic Media And Youth Violence: A CDC issue Brief For Researchers. Atlanta (GA): Centers For Disease Control.

Goleman, D. (1995). Emotional Intelligence. $T . \quad$ (terjemahan: Hermaya). Jakarta: PT Gramedia Pustaka Utama.
Hurlock, E. B. (2011). Psikologi Perkembangan: Suatu Pendekatang Sepanjang Rentang Kehidupan. (terjemahan: Meitasari Tjandrasa dan Muslichah Zarkasih). Jakarta: Erlangga.

Juditha, C. (2011). Hubungan Penggunaan Situs Jejaring Sosial Facebook Terhadap Perilaku Remaja Di Kota Makasar. Jurnal Balai Besar Pengkajian dan Pengembangan Komunikasi dan Informatika Makasar. 13 (1), 1-30. Online. (http://www.jurnal.ugm .ac.id), diakses pada tanggal 20 Oktober 2016. 
Krahe, B. (2005). Perilaku Agresif. (terjemahan: Agustin Hartini). Yogyakarta: Pustaka Pelajar.

Luthfi. (2009). Psikologi Sosial. Jakarta: Lembaga Penelitian UIN Jakarta.

Qomariah, A.N. (2009). Perilaku Penggunaan Internet Pada Kalangan Remaja Di Perkotaan. Jurnal Ilmu Sosial. 2 (2), 1-76. Online.

(http://www.jurnal.ugm .ac.id), diakses pada tanggal 20 Oktober 2016.

Santoso, S.W. (2011). Keterlibatan, Keberhagaan, dan Kompetensi Sosial sebagai Prediktor Kompetisi pada Remaja (Self Explosure). Jurnal Psikologi, 38 (1), 52-60. http://www.jurnal.kominfo.go.id.

Diakses pada tanggal 20 Oktober 2016.

Santrock, J. W. (2002). Life-Span Development: Perkembangan Masa Hidup Jilid II. (terjemahan: Milla Rachmawati). Jakarta: Erlangga.
Santrock, J. W. (2007) Life-Span Developmet: Perkembangan Masa hidup Edisi kelima Jilid II. (terjemahan: Milla Rachmawati) Jakarta: Erlangga.

Shahzad, L. (2012). Self Control And Aggression. Psychological science. 12 (20), 1-37. Online.

(http://www.siencedirect.com). Diakses pada tanggal 8 Oktober 2016.

Turner, J. A (2010). Peer acceptance and friendship: An investigation of their relationship to self-esteem. Journal of Early Adolescence. 5 (34): 1-56.

(http://www.siencedirect.com). Diakses pada tanggal 8 Oktober 2016.

Wahyudiono. (2012). Aktivitas Penggunaan Internet Berdasar Usia. Komunika. Jurnal Komunikasi, Media, dan Informatika. 1 (1) 1-78. Diakses pada April 2012. Online. (http://www.jurnal.ugm.ac.id). Diakses pada tanggal 20 Oktober 2016. 